\title{
Examining the Relationship between Emotional Intelligence and Transformational leadership: Evidence from Hotels and Travel Companies
}

\author{
Azza Maher Emad Abdel-Aal \\ Faculty of Tourism and Hotels \\ Sadat City University
}

\begin{abstract}
Hospitality organizations and travel companies need leaders who are not only emotionally intelligent but who also have an ability to realize and understand the values of their followers that are beneficial both to the service climate and the followers themselves. This study examines the predictive relationship between emotional intelligence and transformational leadership style in hotels and travel companies, investigates how the dimensions of emotional intelligence are associated with supervisor's transformational leadership, assesses if there is any differences in the relationship between emotional intelligence and transformational leadership style in respect to business type. Data were collected from 234 managers (78\% response rate) by using the Emotional Quotient Inventory questionnaire (EQ-I) and from 468 employees (72\% response rate) by using the Multifactor Leadership Questionnaire (MLQ). The results of this study indicate that emotional intelligence is positively related to transformational leadership $(\mathrm{p}<0.05)$. Moreover, a significant predictive relationship ( $\mathrm{p}<0.05$ ) was found between emotional intelligence and transformational leadership style with a variability of $56.8 \%$. Also, the results revealed that the predictive power of emotional intelligence was explained by only the dimensions: "Intrapersonal", "Interpersonal", "Stress Management" and "General mood". In addition, the results showed that no significant interaction ( $p>0.05)$ was found between business type (hotel or Travel Company) and emotional intelligence while predicting transformational leadership style.
\end{abstract}

Key Words: Emotional Intelligence, Transformational Leadership, Hospitality Organizations, Travel Companies.

\section{Introduction}

Emotional intelligence (EI) is thought to associate with success in various aspects of personal and professional life. According to Cherniss (2001) the term EI refers to the ability of person to perceive and express emotion, assimilate emotion in thought, understand and reason with emotion, then control and balance emotions in him/her self and others. In other words, EI is one's ability to be aware of one's own feelings, be aware of others' feelings, to separate among them, and to utilize the information to guide one's thinking trend and behavior (Salovey and Mayer, 1994). From this definition it is observed that definition consists of three levels of abilities: evaluation and expression of emotion, regulation of emotion; using emotions in decision-making.

Goleman et al. (2002) argued that EI is a critical dimension in leadership effectiveness, particularly as leaders deal with teams. Team leaders facilitate team-member interactions and dynamics; build interpersonal trust; inspire team members to implement the organization's strategic vision (Prati et al., 2003).

Emotionally intelligent leaders assess team members' emotional situations in order to discourage detrimental interactions. By constructively resolving conflicts and supporting a relationship of cooperation and trust among members, they contribute to the collective motivation of team members (Schlechter and Strauss, 2008).

As, EI is an organizing of abilities concerned with processing emotions and emotional information (Salovey and Grewal, 2005), It is considered essential in leadership because EI can affect leadership styles and decision making. Specialists are interested in emotionality in representatives at work place, because in stressful situation employees can handle themselves well if they are emotionally intelligent, but if they are not then these types of situations can have a negative impact on the work place. Leadership is undergoing a fundamental transformation today. The transformation from leader as supervisor to leader as partner and coach requires certain abilities on behalf of the leader. Leadership is about what you do with people, not what you do to them. Consequently, it can be accepted that the skills and abilities of transformational 
leadership (TL) would encourage performance and innovation in this rapidly changing marketplace. EI is thought to be an important characteristic in leadership, particularly in TL (Ashkanasy and Tse, 2000).

Transformational leadership style as defined by Bass and Avolio (2000) is a style of leadership in which a leader should create awareness and interest in his/her group, improve the confidence level of individuals and push his/her subordinates towards achievement and growth. Bass (1990) suggested that transformational leaders must have multiple kind of intelligence and that social ability and EI are critical because these are essential to the leader's ability to inspire followers and build relationships. Caruso et al. (2002) support Bass's concept. According to these authors EI underlies a leader's relationship skills. They concluded that organizations should put EI in their consideration during the selection and development of their leaders.

Studies into the relationship between EI and TL spanned almost 17 years, and despite many studies have concluded that intelligence and certain personality traits of leaders seem to be related to TL and leadership efficacy (e.g., Bono and Judge, 2004; Judge et al., 2004), there is still limited empirical evidence that the two concepts are significantly related (Gardenar and stough, 2002; Hunt and Fitzgerald, 2013). Moreover, studies testing the effects of EI on the leadership are rarely done effectively, as it is difficult to ignore the leaders' abilities and personality which influenced in estimation error (Antonakis, et al., 2010).

In addition, there is limited literature dealing with issues about the relation between these two concepts in the hospitality and tourism industry (Koroglu and Koroglu, 2012; Kim et al., 2012). Hence, the present paper attempts to address this gap by examining the predictive relationship between EI and TL style in the tourism sector (hotels and travel companies). Moreover, this research try to identify which dimensions of EI are more associated with a supervisor's TL. Additionally, the study investigates if there is any difference in the relationship between EI and TL style with respect to the business type.

\section{Theoretical Perspectives}

\subsection{The Concept of Emotional Intelligence}

The concept of EI is now widely spread and applied, however, yet the tourism and hospitality industry seems to be a new area for using such a concept. But, today working in the hospitality and tourism industry requires not only high quality of service but also being aware of emotions and managing them in a positive way (Rybochkina, 2010).

According to Brown, et al. (2006) despite, the meaning of intelligences beyond memory and critical thinking had long been reported, it was not until relatively recently that considerable efforts were made to define EI, or that serious popular attention was paid to the concept (Goleman, 1995). Over the last decade considerable attention has been paid to the issues of definition, independence, measurement and impact on organizational productivity (Goleman, 1995, 1998b; Mayer and Salovey, 1997).

Nowadays, El focuses mainly on understanding and accepting emotions as assets as they convey something. When managed intelligently, leaders in tourism industry gain high value from emotions and develop real self-efficacy. EI helps them make better decisions and gains the full responsibility and efforts of those they lead (Freedman, 2007).

EI was first defined by Mayer and Salovey $(1997$, p.18) as "the ability to monitor one's own and others' feelings and emotions, to discriminate among them and to use this information to guide one's thinking and actions". Interest in EI has grown dramatically in the past decade as many definitions of EI were established. While many studies have contributed to this issue, a persuasive EI model developed by Goleman has received prominence. Goleman defined EI as "the capacity for recognizing our own feelings and those of others, for motivating ourselves and for managing emotions well in ourselves and in our relationships" (Goleman, 1998a, p.317). Boyatzis et al. (2000) refined Goleman's (1998a) EI model from five dimensions (self-awareness, self-regulation, motivation, empathy and social skills) to four (selfawareness, self-management, social awareness and relationship management), to control the full scope of emotional competencies. This has become a widely used model of EI. 


\section{Examining the Relationship between Emotional Intelligence and Transformational leadership: Evidence from Hotels and Travel Companies}

Based on the concept of Gardner (1999) intrapersonal and interpersonal intelligences provide a basis for the conceptualization of EI. Since, intrapersonal intelligence is the ability of a leader to understand his own emotions, interpersonal intelligence is the leader's ability to understand the emotions of others. Goleman (2001) concluded that this intelligence is associated with social competencies, such as empathy and social skills.

Due to the differences in definitions and explanation of EI concept, researchers have developed a variety of assessment devices to measure EI. (e.g. Bar-On, 1997; Rahim et al., 2002).

Of the assessment devices presented within the research on trait EI, self-report measures, such as the Bar-On (1997) Emotional Quotient Inventory (EQ-i) or the Swinburne University EI Test (Palmer and Stough, 2001), prove to be prominent. In addition to the trait-based measures, which are generally based on participants self-reporting their levels of EI, there are also ability-based measures, such as the MayerSalovey-Caruso EI-test (Mayer et al., 2002), which depend on performance via requiring participants to engage in tasks that assess EI. On these measures, participants may be asked to: identify the emotions conveyed by pictures; report on how they would manage or change emotions in response to speculative scenarios; relate feelings to sensory stimuli; report on circumstances that would be expected to change emotional states (Mayer et al., 2004). Reactions are then scored according to procedures or expert ratings of the different options.

\subsection{The Construct of Emotional Intelligence}

Scholars have introduced two distinctly different, but related, models of EI (Caruso et al., 2002; Ciarrochi et al., 2001).The first model, i.e. the ability model, defines EI as a set of abilities that involves perceiving and reasoning abstractly with information that emerges from feelings (Mayer and Salovey, 1997). The second model or mixed model, which arises largely from the work of Bar-On (1997), defines EI as the ability related to social behaviours, traits and competencies (Goleman, 1995, 1998a; Bar-On, 1997). Côté et al. (2010) proposed that EI should not be considered a unique human ability until there was an appropriate instrument for the constructs measurement. Mayer et al., (1997) developed an ability-based EI test the Multifactor EI. Thus, the measurement of each type of EI has been worked on from different angles of thought and assumptions (Danquah and Wireko, 2014).

\subsection{Emotional Intelligence Components}

The Bar-On (EQ-i) divided EI into five major components or dimensions. Bar-On (1996) labeled these five components: 'intrapersonal'; 'interpersonal'; 'adaptability'; 'stress management'; 'general mood'. While, Goleman (1996) derived five dimensions for EI (i.e. self-awareness; self-regulation; social skill; empathy; motivation), that were later revised by Goleman (1997) into four dimensions: self-awareness; selfregulation; social awareness; social skill (Mandell and Pherwani, 2003).

Lately, a number of researchers have redefined Goleman's (1998b) five dimensions of EI (Rahim et al., 2002; 2006 and Polychroniou, 2009). The explanation of these dimensions is presented in Table 1: 
Table 1: The Five Dimensions of EI

\begin{tabular}{|c|c|c|c|}
\hline & Definition & Hallmarks & Definition \\
\hline & \multicolumn{2}{|c|}{ Goleman (1998b) } & Rahim et al. (2002, 2006) \\
\hline $\begin{array}{l}\text { Self- } \\
\text { Awareness }\end{array}$ & $\begin{array}{l}\text { - The ability to recognize } \\
\text { and understand your } \\
\text { moods, emotions, and } \\
\text { drives, as well as their } \\
\text { effects on others }\end{array}$ & $\begin{array}{l}\text {-Self-confidence } \\
\text {-Realistic self } \\
\text { assessment } \\
\text {-Self-deprecating } \\
\text { sense of humor }\end{array}$ & $\begin{array}{l}\text { Associated with the ability to be aware } \\
\text { of which emotions, moods, and } \\
\text { impulses one is experiencing and why. } \\
\text { This also includes one's awareness of } \\
\text { the effects of his or her feelings on } \\
\text { others. }\end{array}$ \\
\hline $\begin{array}{l}\text { Self- } \\
\text { Regulation }\end{array}$ & $\begin{array}{l}\text {-The ability to control or } \\
\text { redirect impulses and } \\
\text { moods. } \\
\text {-The propensity to suspend } \\
\text { judgment and think before } \\
\text { acting }\end{array}$ & $\begin{array}{l}\text {-Trustworthiness } \\
\text { and integrity } \\
\text {-Comfort with } \\
\text { ambiguity } \\
\text {-Openness to } \\
\text { change }\end{array}$ & $\begin{array}{l}\text { Refers to the ability to keep one's own } \\
\text { emotions and impulses in check, to } \\
\text { remain calm in potentially volatile } \\
\text { situations, and to maintain composure } \\
\text { irrespective of one's emotions. }\end{array}$ \\
\hline Motivation & $\begin{array}{l}\text {-A passion to work for } \\
\text { reasons that go beyond } \\
\text { money or status } \\
\text {-A propensity to pursue } \\
\text { goals with energy and } \\
\text { persistence }\end{array}$ & $\begin{array}{l}\text {-Strong drive to } \\
\text { achieve } \\
\text {-Optimism, even in } \\
\text { the face of failure } \\
\text {-Organizational } \\
\text { commitment }\end{array}$ & $\begin{array}{l}\text { Represents the ability to remain } \\
\text { focused on goals despite setbacks, to } \\
\text { operate from hope of success rather } \\
\text { than fear of failure, delaying } \\
\text { gratification, and to accept change to } \\
\text { attain goals. }\end{array}$ \\
\hline Empathy & $\begin{array}{l}\text {-The ability to understand } \\
\text { the emotional makeup of } \\
\text { other people } \\
\text {-Skill in treating people } \\
\text { according to their } \\
\text { emotional reactions }\end{array}$ & $\begin{array}{l}\text {-Expertise in } \\
\text { building and } \\
\text { retaining talent } \\
\text {-Cross-cultural } \\
\text { sensitivity } \\
\text {-Service to clients } \\
\text { and customers }\end{array}$ & $\begin{array}{l}\text { One's ability to understand the feelings } \\
\text { transmitted through verbal and } \\
\text { nonverbal messages, to provide } \\
\text { emotional support to people when } \\
\text { needed, and to understand the links } \\
\text { between others emotions and } \\
\text { behavior. }\end{array}$ \\
\hline Social Skill & $\begin{array}{l}\text {-Proficiency in managing } \\
\text { relationships and building } \\
\text { networks } \\
\text {-An ability to find } \\
\text { common ground and build } \\
\text { rapport }\end{array}$ & $\begin{array}{l}\text {-Effectiveness in } \\
\text { leading change } \\
\text {-Persuasiveness } \\
\text {-Expertise in } \\
\text { building and } \\
\text { leading teams }\end{array}$ & $\begin{array}{l}\text { Associated with one's ability to deal } \\
\text { with problems with-out demeaning } \\
\text { those who work with him or her, to not } \\
\text { allow own or others' negative feelings } \\
\text { to inhibit collaboration, and to handle } \\
\text { affective conflict with tact and } \\
\text { diplomacy. }\end{array}$ \\
\hline
\end{tabular}

Source: Developed from (Goleman, 1998b; Polychroniou, 2009)

Briefly, Emotional intelligence Components are critical powerful tools for exceeding goals, improving critical work relationships, and creating a healthy, productive workplace and organizational culture.

\subsection{Transformational Leadership}




\section{Examining the Relationship between Emotional Intelligence and Transformational leadership: Evidence from Hotels and Travel Companies}

Over the past 25 years, it has been observed that the leadership style of most relevance to tourism and hospitality leaders has been TL (Avolio and Gardner 2005; Brownell, 2010). The concept of TL was first presented by Burns (1978) in order to differentiate leaders who established meaningful, inspiring followers to work toward common organizational goals and motivating relationships with subordinates and followers from those who depend extensively on exchanges or transactions to generate results (Cavazotte et al., 2012). In other words, TL is usually used to differentiate leadership and management (Duckett and Macfarlane, 2003).

TL has received significant consideration in business areas due to its positive effects on employees' behaviors and results such as increased in-role performance (Ölçer et al., 2014). The past two decades have witnessed a growing interest in TL as key to effectiveness in high-touch hospitality and tourism environments (Brownell, 2010). Furthermore, many studies in tourism and hospitality concluded that the shared values inspired by transformational leaders were among the most important variables shaping follower motivation and satisfaction (Clark et al., 2009).

Transformational leaders should have the ability to motivate subordinates to do more than what is expected; increase subordinates awareness about new outcomes and motivate them to transcend their own needs for the sake of their team (Bass and Riggio, 2008; Polychroniou, 2009). Transformational leaders frequently do not fit within a traditional organization and may lead a social movement rather than a formal organization (Hellriegel and Slocum, 2004; Hellriegel et al., 2005). Transformational leaders respond to the needs of individual followers by empowering them and by aligning the objectives and goals of the subordinates, the leader, the group, and the organization (Bass and Riggio, 2008; Mathew and Gupta, 2015; Cavazotte et al., 2012).

Moreover, leaders who have empathy are likely to support subordinates' needs, take an active interest in them, respond to changes in their emotional states, and to work together to attain objectives on team basis (Rahim et al., 2002). It is reported that empathy is likely to be associated with individualized consideration. While, social skills that are associated with enabling followers to engage in desirable behaviors are likely to be associated with intellectual stimulation (Goleman, 2001; Rahim et al., 2006).

Generally, employees are likely to respect and emotionally identify with a leader who is considerate and is willing to help followers to be effective, enhance their use of an integrating style for handling conflict and improve their job performance (Rahim et al., 2002, 2006).

Five dimensions of TL have been identified in the literature: "idealized influence" (attributed), "idealized influence "(behavioral)," individual consideration", "inspirational motivation", and "intellectual stimulation" (Bass and Avolio, 1997). In contrast, some other studies (Bass and Riggio, 2006) have developed only four clear components of TL, namely: (1) idealized influence or charisma (which describes leaders who behave in ways that allow them to serve as role models for their subordinates; take stands on difficult issues, present their most important values, and who are admired, respected, and trusted); (2) inspirational motivation (which describes leaders who behave in ways that motivate and inspire subordinates, e.g., by talking optimistically with enthusiasm or providing meaning and challenge to their work and spreading inspiring visions); (3) intellectual stimulation (which describes leaders who stimulate new perspectives and ways of doing things, reshaping problems, approaching situations in new ways and promote thinking processes that favor creativity and innovation); and finally, (4) individualized consideration (which describes leaders who create new learning opportunities along with a supportive climate, listen attentively and deal with others as individuals who have differences in terms of needs and desires) (Bass and Riggio, 2006; Lam and O'Higgins, 2012; Harms and Credé, 2010; Follesdal and Hagtvet, 2013).

\subsection{Emotional Intelligence and Transformational Leadership Behaviour}

Several researchers have argued that EI as an ability is critical to effective leadership generally (Caruso et al., 2002; Rosete and Ciarrochi, 2005) and to TL specifically (Ashkanasy and Tse, 2000; Bass and Riggio, 2006; Follesdal and Hagtvet, 2013). However, a number of studies already have discovered critical relationships between EI and TL (Ashkanasy and Daus, 2005; Clarke, 2010; Harms and Credé, 2010), as 
well as a number particularly inside a project context (Butler and Chinowsky, 2006, Clarke, 2010; Harms and Credé, 2010).

Ashkanasy and Daus (2005), and Cavazotte et al. (2012) concluded that more EI is required for individuals who will be leaders. Thus, leaders who have the ability to perceive their emotions and understand the impacts of their actions and on the actions of others should have a greater probability of supporting effective leadership (Day and Carroll, 2004).

Mathew and Gupta (2015) observed several significant and critical correlations between TL and EI. First, the ability to control and to manage feelings within oneself and others is significantly correlated with inspirational motivation and individualized consideration. Second, the ability to drive emotions within oneself and others is correlated significantly with idealized influence. The EI level of leaders keeps their ability to manage the feeling and emotions of the teams and motivate them to meet its objectives (Lutzo, 2005). Such leaders inspire their followers through positive thoughts and clear vision (Goleman et al., 2002).

Furthermore, meta-analytic studies have suggested that EI is a vital predictor of personal success than personality traits (Van Rooy and Viswesvaran, 2004). In addition, a respectable number of reviews have observed a significant correlation for EI and TL (Cavazotte et al., 2012; Rosete and Ciarrochi, 2005; Côté et al., 2010).

Leaders with high EI are self-aware and they understand themselves. They are hopeful, compassionate and mindful. Effective leaders are familiar with their people's feelings and motivate them in a positive direction. This resonance comes naturally to emotionally intelligent leaders and this resonance boosts performance (Goleman et al., 2002).

A number of empirical studies, on the other hand, have failed to detect a significant relationship between EI and TL (Harms and Crede, 2010; Hunt and Fitzgerald, 2013). Some have argued that EI suggested components are fraught with problems of validity and reliability, and that the support for the EI construct may be based more on speculative thinking than on empirical evidence. Others have focused on the problem of common method variance in studies using the same source data to examine the relationship between EI and TL. This problem, which can be attributed to the claim that correlations are artificially inflated when common method bias is not accounted for, is a serious problem in several of the same-source research studies into the EI-TL relationship (Lindebaum and Cartwright, 2010; Podsakoff et al., 2003).

It could be concluded that there remains limited empirical evidence that EI and TL are significantly related. As, recognized experts in the field of EI, along with researchers in the area of TL, still argue that dimensions of EI such as emotional recognition, empathy and emotional processing are central to TL behavior (Hunt and Fitzgerald, 2013).

\section{Methodology:}

Based on previous research in the areas of TL and EI (Lopez-Zafra et al., 2012; Mathew and Gupta, 2015) the current study was designed to determine the predictive relationship between EI and TL style in tourism sector (hotels and travel companies). Moreover, the present research tries to identify which dimensions of EI are more associated with supervisor's TL. Additionally, the study investigated if there is any difference in the relationship between EI and TL style with respect to the business type.

\subsection{Data Collection}

\subsubsection{Measuring Instruments}

To achieve the study objectives, two questionnaires were developed (see the appendix). The first assessed intelligent emotional scores as rated by managers themselves, the second assessed the TL style of managers as judged by subordinates' perception of their immediate managers. The study used the term leader referring to the manager who was the focus of this research. While, the term subordinate used for referring to the employees under the manger's supervision.

\section{- Emotional Intelligence Questionnaire}

The design of the EI questionnaire was based on EQ-i (Bar-On, 1996). A variety of models and measures have been developed to measure EI (Goleman, 1995; Mayer and Salovey, 1997), EQ-i, however, is 


\section{Examining the Relationship between Emotional Intelligence and Transformational leadership: Evidence from Hotels and Travel Companies}

considered a mixed model, since it defines EI as a mixture of emotion-related competencies, personality traits and dispositions (Palmer et al., 2003).The EQ-i can best be described as a self-report inventory of 133 declarative statements phrased in the first-person singular. Leaders are required to indicate the degree to which each statement is true of the way they typically think, feel or act on a five-point scale (1=Very Seldom or Not true of me; 5=Very often true of me or True of me) (Bar-On, 1996).

The EQ-i (Bar-On, 1996), which was originally designed in 1980 by Bar-On to measure EI, categorizes its items into five main components and 15 factorial components. The five main components are: 'Intrapersonal'; 'Interpersonal'; 'Adaptability'; 'Stress Management'; 'General Mood'. Bar-On (1996) described the five components as follows:

- The first component, Intra-personal, is a scale that assesses the inner self. Individuals who score high on this scale are considered to be in touch with their emotions, they feel good about themselves, and they feel positive about the way things move in their lives.

- The second component, Inter-personal, is characteristic of responsible and dependable individuals who have good people skills. Individuals who score high on this scale understand, interact and relate well with others.

- The third component, Adaptability, is a sign of how well leaders are able to cope with environmental demands and pressures.

- The fourth component, Stress Management, reflects how people handle stress.

- The fifth and final component, General Mood, is an indicator of an individual's ability to enjoy life.

A short form was developed using the large (EQ-i). The goal was to develop a scale that would include a sufficient number of items to reliably assess the EI dimensions (Intrapersonal, Interpersonal, Stress Management, Adaptability and general mood (the sum of which would render a total EQ-i scale). The questionnaire is made up of two sections; the first section was designed to elicit demographic information of the leader; the second section consisted of 59 items or statements which measure EI, for which leaders were asked to rate them. These items are divided as follows:

- Intrapersonal Skills included the sub scales of Self-Regard (4 items), Emotional Self-Awareness (4 items), Assertiveness (4items), Independence (4 items) and Self-Actualization (4 items).

- Interpersonal Skills associated with the sub scales of Empathy (3 items), Social Responsibility (4 items) and Interpersonal Relationship (4 items).

- Stress-management Scales have to do with: Stress Tolerance (4 items) and Impulse Control (4 items).

- Adaptability Scales included the sub scales: Reality-Testing (4 items), Flexibility (4 items) and Problem-Solving (4 items).

- General Mood associated with the sub scales: Optimism (4 items) and Happiness (4 items).

\section{- Transformational Leadership Questionnaire}

This study used The Multifactor Leadership Questionnaire (MLQ) to determine the leadership style of individuals. MLQ was developed by Bass and Avolio (1996) and has been shown to be a reliable instrument that has validity in the measurement of TL and other dimensions of a full range of leadership models (Antonakis, 2003). According to Alsayed et al. (2012) it is widely used for measuring leadership styles. Further, it was utilized in several empirical researches, particularly those concerned with the relationship between leadership styles and other dimensions.

Validation studies on the scale have reported Cronbach's alpha to be as follows for each of the subscales: idealized influence $(\alpha=0.75)$, inspirational motivation $(\alpha=0.72)$, intellectual stimulation $(\alpha=$ 0.72 ) and individualized consideration $(\alpha=0.64)$ (Sosik and Godshalk, 2000).

This scale usually answered by the subordinates using a five-point Likert scale. The scale points are $1=$ not at all, $2=$ once in a while, $3=$ sometimes, $4=$ fairly often and $5=$ frequently, if not always. The chosen 
16 items of MLQ-Form (Bass and Avolio, 1996) were very slightly modified (e.g. "the person I am rating" was changed to read, "my manager") to make the verbiage appropriate for the particular situation. This questionnaire provides a description of the leadership style. Twelve descriptive statements (Every dimension is measured by three individual items), assessing only TL, are listed under the following dimensions:

Dimension1. Idealized Influence ask about whether leader reached to subordinates' trust, keep on their faith and respect, shows dedication to them, appeals to their aims and dreams, and present a role model.

Dimension2. Inspirational motivation measures the degree to which leader provides a vision, and try to make others feel and appreciate their work, uses appropriate procedures, and orders help others focus on their work

Dimension3. Intellectual stimulation shows the degree to which leaders encourage their followers to be creative in solving old problems in new ways, and create an environment that is tolerant of seemingly extreme positions, and helps people to question their own values and beliefs and those of the organization.

Dimension4. Individualized consideration identifies the degree to which leaders show interest in others' well-being, assigns projects individually, and pays attention to those who seem less involved in the group. In other words, it focuses on understanding the needs of each follower and works continuously to get them to develop to their full potential.

The dependent and independent variables of the study are suggested to be in a theoretical proposed model, see figure 1 .

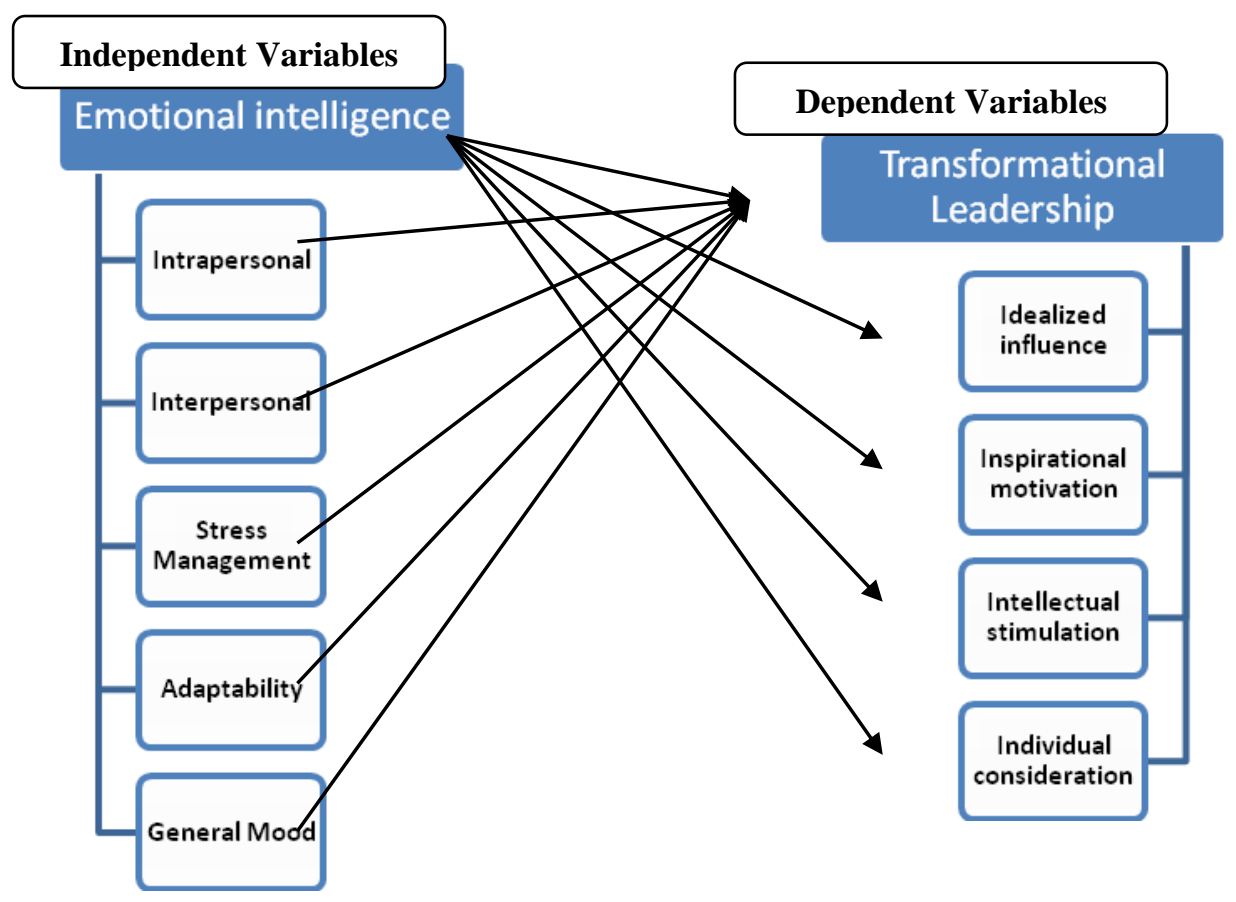

Figure 1: Theoretical Proposed Model for Field Study

The initial questionnaires were prepared and a pre-test was conducted with two identified groups for comments. The two identified groups were 5 academic staff, 16 leaders (managers) and 17 employees in hotels and travel agents. The purpose of the pre-test was to detect potential problems in the questionnaire design, clarity, and wording (Zikmund et al., 2013). They commented positively on the overall layout, instruction and design of the questionnaire. They also had no serious problem with clarity, or wording. However, a few items were reworded after the pilot exercise to improve the comprehensibility and clarity of the questionnaire. The questionnaires' re-probe coefficient equaled 84.06 (EI questionnaire) and 79.67 (TL questionnaire). This constant verified the reliability of the questionnaires. The questionnaires were distributed to hotels and travel agencies by the researchers themselves or by e-mail from February 1 to April 25, 2015. 


\section{Examining the Relationship between Emotional Intelligence and Transformational leadership: Evidence from Hotels and Travel Companies}

\subsubsection{The Target Population, Sampling and Procedures}

The target population of this study was managers or leaders in five-star hotels and travel companies category "A" in Egypt, These categories of hotels and travel companies are chosen as they are believed to be more knowledgeable and to have a basic understanding and acquaintance with the topics of research in order to obtain meaningful data.

Therefore, data in this research were collected using the multistage sampling method. Firstly, Greater Cairo has been selected as the studied area because it is convenient for the researchers due to time and cost concerns. According to the Egyptian hotel and travel agents guides (2013) there are 29 five-star hotels and 1277 travel agents category "A". The random sample is appropriate to be used. The sample units of each hotel and travel agent have been selected randomly as every hotel and company is given equal opportunities of being selected. Secondly, the data were collected using the purposive sampling method. Since, the purposive sample was appropriate to be used for criterion sample (Lisa, 2008). In other words, this sample was preferred to be used if the characteristics of individuals are used as the basis of selection (Wilmot, 2002).

The population elements (managers) are selected on the basis of three inclusion criteria: (1) the manager him/her self had to have completed at least one year in his/her position as a leader; (2) the manager had to have four or more subordinates under his/her leadership; (3) at least two subordinates who completed the leadership measures questionnaire had to have reported directly to the leader for at least three months.

The procedures of research were divided into two stages: Stage one: A total of 29 five-star hotels and 110 travel agents were invited to participate in the study, 17 hotels and 85 travel agents agreed to provide access to their employees. Stage two: the researchers contacted executives or human resources managers of the chosen organizations in order to identify managers who met the inclusion criteria. A total of 300 managers (e.g. vice president, high level managers, middle managers, department head and supervisors) and 650 subordinates were approached individually and asked whether they would be willing to participate in this study. The researchers received the approval of 234 managers and their 468 subordinates with a response rate $78 \%$ and $72 \%$ respectively, to participate in this study. Every subordinate was provided with a unique code for his/her manager. They were asked to write this code on their questionnaire form to facilitate the data analysis. Participants were provided also with a brief explanation of the terms "EI" and "TL" which were the core concepts in this research.

\subsection{Data Analysis}

Different statistical techniques using SPSS 17 were applied to analyze the data. The reliability analysis performed to assess the internal consistency of the measurement scales and Cronbach Alpha coefficients $(\alpha)$ of the scales were computed. Moreover, Descriptive statistics such as mean scores and standard deviations were computed according to the studied variables. In addition, Spearman correlation analysis was conducted to examine the associations among the dimensions of EI and TL. Finally, series of regression analysis were conducted. Specifically, simple separate and multi - regression analyses were conducted to assess the effects of EI on the TL. Standardized beta was used for all of these regression analyses. Statistical significance was considered for $\mathrm{P}$ values less than 0.05 .

\section{Results and Discussion}

\subsection{Sample Characteristics}

To begin analyzing the demographic and leadership data for each participant were obtained. In the total investigation, 234 managers were tested of which 141 (60.3\%) were males and 93 (39.7\%) females. The higher percent of the participants' age was less than 35 years, 108 (46.2\%), then from 35 to 45 years 73 $(31.2 \%)$, and more than 45 year $53(22.6 \%)$. The leadership or supervisory experience of the participants ranged from 1 year to more than 10 years with a highest experience in less than 5 years $102(43.6 \%)$. Department head and supervisor level of participants represents the highest percent $142(60.7 \%)$, followed by participants of middle managers $45(19.2 \%)$, and the rest were vice presidents $12(5.1 \%)$ and high level managers $35(15 \%)$. The higher percent of education level of the participants was College/University 185 (79.1\%), then Secondary/High School 36 (15.4\%), and postgraduate degree 13 (5.6\%). Finally, the leaders 
were working in a team, where less than 10 members represent the highest percent 99 (42.3\%), then from 1020 members 91 (38.9\%), and More than 20 members 44 (18.8\%).

\subsection{Scale Reliability}

After data imputation had been completed and average emotional scores on each of the EI subscales and TL had been calculated, coefficient alpha was computed for each of the four leadership scales and the overall EI measure. Overall, each of the scales demonstrated acceptable reliability in the present context. The lowest reliability $(\alpha=0.72)$ was associated with the general mood sub scale. However, even this is above the minimum reliability level recommended by Nunnally and Bernestein (1994).

\subsection{Descriptive Statistics and Correlation Analysis}

Descriptive Statistics means and standard deviations for each of the measures are displayed in Table 2. The descriptive statistics showed that mean score for TL was $3.04(\mathrm{SD}=0.71)$, indicating that the managers reflected a moderate degree of TL. Regarding the dimensions of TL, the results show that Inspirational motivation scores the highest mean $=3.33$ with $\mathrm{SD}=0.77$. This indicated that the managers of the study try to provide a vision to their employees, help others focus on their work, and make others feel their work is significant. While, the dimension "Individual consideration" scores the lowest mean $=2.67$ with $\mathrm{SD}=0.86$ ) revealing that the managers had no serious willing to focus on understanding the needs of each follower or works continuously to get them to develop to their full potential.

The level of EI of managers was relatively higher than the mean score for TL ( $M=3.32, S D=0.55)$. This result provided many insights especially to the areas where the managers showed a high level of EI. As illustrated in Table 2, the mean scores for the five dimensions of EI suggested that the managers in tourism had high general mood including optimism and happiness $(\mathrm{M}=3.30, \mathrm{SD}=0.60)$, The scale with the lowest mean score was Interpersonal $(\mathrm{M}=3.18, \mathrm{SD}=0.56)$, indicating that the managers had a low level of empathy, social responsibility and Interpersonal Relationship.

Regarding the relation between EI and TL, The correlation between the dimensions of EI and TL and the complete scale of EI and TL were calculated. Table 2 illustrates the correlation matrix. As expected, a high positive correlations between EI and its dimensions exist; it ranges from (0.83) for Intrapersonal to (0.94) for Interpersonal. Similarly, correlations between each of the leadership measures were significant, ranging from (0.80) with Individual consideration to (0.86) with Inspirational motivation and Intellectual stimulation. The results showed that EI, in line with expectations, significantly and positively correlated with overall TL ( $\mathrm{r}=0.67, \mathrm{p}<0.05)$ and for its five dimensions, namely Intrapersonal $(\mathrm{r}=0.51)$, Interpersonal $(\mathrm{r}=.66)$, stress Management $(r=0.68)$, Adaptability $(r=0.52)$ and General mood $(r=0.56)$. All of these correlations were statistically significant with $(\mathrm{p}<0.05)$.

According to the results of table 2, It was also observed that EI is associated with the four aspects of TL . Since, EI positively correlated to these aspects, ranging from $r=0.51$ with "Individual consideration" to $\mathrm{r}=0.73$ with "Intellectual stimulation". This meant that if the managers have high EI, it is expected to follow the TL style. In other words, these positive correlations indicate the possibility that the five dimensions of EI are good predictors of TL. 
Examining the Relationship between Emotional Intelligence and Transformational leadership: Evidence from Hotels and Travel Companies

Table 2: Descriptive Statistics and Inter-Correlations of All Study Variables

\begin{tabular}{|c|c|c|c|c|c|c|c|c|c|c|c|}
\hline & 1 & 2 & 3 & 4 & 5 & 6 & 7 & 8 & 9 & 10 & 11 \\
\hline $\begin{array}{l}\text { 1- } \\
\text { Intrapersona }\end{array}$ & - & & & & & & & & & & \\
\hline $\begin{array}{l}\text { 2- } \\
\text { Interpersona }\end{array}$ & $\begin{array}{l}0.79(* \\
*)\end{array}$ & - & & & & & & & & & \\
\hline $\begin{array}{l}\text { 3-stress } \\
\text { Management }\end{array}$ & $\begin{array}{l}0.77(* \\
*)\end{array}$ & $\begin{array}{l}0.88(* \\
*)\end{array}$ & - & & & & & & & & \\
\hline $\begin{array}{l}\text { 4- } \\
\text { Adaptability }\end{array}$ & $\begin{array}{l}0.76\left(^{*}\right. \\
*)\end{array}$ & $\begin{array}{l}0.85(* \\
*)\end{array}$ & $\begin{array}{l}0.83(* \\
*)\end{array}$ & - & & & & & & & \\
\hline $\begin{array}{l}\text { 5-General } \\
\text { mood }\end{array}$ & $\begin{array}{l}0.83(* \\
*)\end{array}$ & $\begin{array}{l}0.78(* \\
*)\end{array}$ & $\begin{array}{l}0.81(* \\
*)\end{array}$ & $\begin{array}{l}0.57(* \\
*)\end{array}$ & - & & & & & & \\
\hline $\begin{array}{l}\text { 6-Emotional } \\
\text { Intelligence }\end{array}$ & $\begin{array}{l}0.83(* \\
*)\end{array}$ & $\begin{array}{l}0.94(* \\
*)\end{array}$ & $\begin{array}{l}0.92(* \\
*)\end{array}$ & $\begin{array}{l}0.86{ }^{*} \\
*)\end{array}$ & $\begin{array}{l}0.86 \text { (* }^{*} \\
*)\end{array}$ & - & & & & & \\
\hline $\begin{array}{l}\text { 7-Idealized } \\
\text { influence }\end{array}$ & $\begin{array}{l}0.62(* \\
*)\end{array}$ & $\begin{array}{l}0.566^{*} \\
*)\end{array}$ & $\begin{array}{l}0.49{ }^{*} \\
*)\end{array}$ & $\begin{array}{l}0.42(* \\
*)\end{array}$ & $\begin{array}{l}0.666^{*} \\
*)\end{array}$ & $\begin{array}{l}0.57(* \\
*)\end{array}$ & - & & & & \\
\hline $\begin{array}{l}8- \\
\text { Inspirational } \\
\text { motivation }\end{array}$ & $\begin{array}{l}0.64(* \\
*)\end{array}$ & $\begin{array}{l}0.70\left(^{*}\right. \\
*)\end{array}$ & $\begin{array}{l}0.69 \text { (* }^{*} \\
*)\end{array}$ & $\begin{array}{l}0.54\left(^{*}\right. \\
*)\end{array}$ & $\begin{array}{l}0.59 \text { (* } \\
*)\end{array}$ & $\begin{array}{l}0.69 \text { (* } \\
*)\end{array}$ & $\begin{array}{l}0.71(* \\
*)\end{array}$ & - & & & \\
\hline $\begin{array}{l}\text { 9- } \\
\text { Intellectuall } \\
\text { stimulation }\end{array}$ & $\begin{array}{l}0.55(* \\
*)\end{array}$ & $\begin{array}{l}0.71(* \\
*)\end{array}$ & $\begin{array}{l}0.74(* \\
*)\end{array}$ & $\begin{array}{l}0.66(* \\
*)\end{array}$ & $\begin{array}{l}0.61(* \\
*)\end{array}$ & $\begin{array}{l}0.73(* \\
*)\end{array}$ & $\begin{array}{l}0.62(* \\
*)\end{array}$ & $\begin{array}{l}0.71(* \\
*)\end{array}$ & - & & \\
\hline $\begin{array}{l}\text { 10- } \\
\text { Individual } \\
\text { consideratio } \\
\text { n }\end{array}$ & $\begin{array}{l}0.32(* \\
*)\end{array}$ & $\begin{array}{l}0.51(* \\
*)\end{array}$ & $\begin{array}{l}0.56(* \\
*)\end{array}$ & $\begin{array}{l}0.56(* \\
*)\end{array}$ & $\begin{array}{l}0.40\left(^{*}\right. \\
*)\end{array}$ & $\begin{array}{l}0.51(* \\
*)\end{array}$ & $\begin{array}{l}0.60(* \\
*)\end{array}$ & $\begin{array}{l}0.52(* \\
*)\end{array}$ & $\begin{array}{l}0.73(* \\
*)\end{array}$ & - & \\
\hline $\begin{array}{l}\text { 11- } \\
\text { Transformat } \\
\text { ional } \\
\text { leadership }\end{array}$ & $\begin{array}{l}0.51(* \\
*)\end{array}$ & $\begin{array}{l}0.66(* \\
*)\end{array}$ & $\begin{array}{l}0.68\left(^{*}\right. \\
*)\end{array}$ & $\begin{array}{l}0.52(* \\
*)\end{array}$ & $\begin{array}{l}0.56 \text { (* }^{*} \\
*)\end{array}$ & $\begin{array}{l}0.67(* \\
*)\end{array}$ & $\begin{array}{l}0.81(* \\
*)\end{array}$ & $\begin{array}{l}0.86(* \\
*)\end{array}$ & $\begin{array}{l}0.86{ }^{*} \\
*)\end{array}$ & $\begin{array}{l}0.80\left(^{*}\right. \\
*)\end{array}$ & \\
\hline Mean & 3.22 & 3.1 & 3.20 & 3.23 & 3.30 & 3.32 & 3.18 & 3.33 & 2.97 & 2.67 & $\begin{array}{l}3.0 \\
4\end{array}$ \\
\hline $\begin{array}{l}\text { Standard } \\
\text { Deviation }\end{array}$ & .71 & .56 & .57 & .46 & .60 & .55 & 0.85 & 0.77 & 0.79 & 0.86 & .71 \\
\hline
\end{tabular}

$(* *)$ The correlation is significant at the $(0.05)$ level. 
These results match with the past studies that concluded that leaders with high El exhibit transformational behaviors and this relationship exists because of the strong emotional relationship that is obvious between the leader and the follower in the TL style (Goleman, 1995; Megerian and Sosik, 1996).

Moreover, relatively recent studies such as of Sivanathan and Fekken (2002), Gardner and Stough (2002) supported the existence of a strong relationship between TL and overall emotional; also the studies of Mandell and Pherwani (2003), Lopez-Zafra et al. (2012) and Mathew and Gupta (2015) explored the relationship between El and TL and found that El (including all components) shared positive relationships with each subscale of TL.

\subsection{Regression Analysis}

A series of regressions were conducted to explore the predictive power of EI for TL. Table 3 is the model summary for the prediction of TL by EI. From the table, EI accounts for $56.8 \%$ variability (influence) on TL. The Adjusted R Square suggests that EI accounts for $56.6 \%$ of variability in TL. Generally, the model is moderately strong. However, it could be viewed as a strong model, considering the fact that $56.8 \%$ is the variability contributed by only EI. Moreover, the value of $r=0.753$ shows a fairly positive correlation ( $r$ $>0.05$ ) between EI and TL.

Table 3: Regression Matrix to Identify the Relationship between EI and TL

\begin{tabular}{lccccc}
\hline * Model & $\begin{array}{c}\text { Un-standardized } \\
\text { Coefficients }\end{array}$ & & \multicolumn{3}{c}{$\begin{array}{c}\text { Standardized } \\
\text { coefficients }\end{array}$} \\
\hline & $\mathrm{B}$ & Std error & Beta & $\mathrm{t}$ & Sig \\
\hline Constant & -0.058 & 0.180 & & -0.319 & 0.750 \\
\hline Emotional intelligence & 0.959 & 0.055 & 0.753 & 17.448 & 0.000 \\
\hline
\end{tabular}

Note: $\mathrm{R}^{2}=.568$, Adj. $\mathrm{R}^{2}=.566, \mathrm{R}=.753, \mathrm{~F}=304.448, p<.005$.

* Dependent variable: Transformational leadership

* Regression equation can be formed as $\mathrm{TL}=-0.058+0.95 \mathrm{EI}$

The result presented in table 3 may justify this argument. Since, an F-test associated with the prediction of TL by EI. From the table, the test is also significant at $5 \%$ significance level, $F=304.448, p=$ .000. Thus, EI significantly predict TL in a linear function. This finding corroborates the argument that the model found in Table 3 is not necessarily weak. Moreover, additional justification to this is the significance of the $t$-test associated with EI . The significance of the $t$-test $(\mathrm{p}$ value $=.000)$ suggests that EI is a significant predictor of TL.

These results match with the studies of Sosik and Megarian (1999), and Harms and Credé (2010) who suggested several aspects of EI that would facilitate TL. The results also are consistent with the study of Ashkanasy and Tse (2000) and Harms and Credé (2010) who state EI to be an important characteristic in leadership, particularly in TL.

On the contrary, the results of this study did not match with other previous studies which concluded no indication that EI as operationalized and measured is of any value in understanding or exploring the leadership style and Individuals who reported EI (high EI) were not more likely to demonstrate TL (Brown et al., 2006; Lindebaum and Cartwright ,2010).

Moreover, the study of Cavazotte et al. (2012) found that when 'other' individual differences (intelligence, personality) associated with leadership are taken into account, the predictive power of EI becomes frail. 


\section{Examining the Relationship between Emotional Intelligence and Transformational leadership: Evidence from Hotels and Travel Companies}

In order to find significant predictors variables of TL multi-regression analysis was run. The result revealed that among five variables which were entered as a block, (Intrapersonal, Interpersonal, stress Management, adaptability and General mood) were significantly contributed towards the variance of leadership effectiveness as predictors.

Table 4 is the model summary in the prediction of TL from the five dimensions of EI. The R Square value shows that the five dimensions are strong predictors of TL. In other words, the five dimensions of EI account for $65.6 \%$ of variability (influence) in TL. At 5\% significance level, the test is statistically significant, $\mathrm{F}=86.98, \mathrm{p}=.000$. The significant $\mathrm{F}$-value provides evidence for the fact that the model fits the data and the model is valid. This implies that the five dimensions of EI are significant linear predictors of TL.

Table 4: Regression Matrix to Identify the Relationship between EI and TL Dimensions

\begin{tabular}{lccccc}
\hline * Model & $\begin{array}{c}\text { Un-standardized } \\
\text { Coefficients }\end{array}$ & & \multicolumn{3}{c}{$\begin{array}{c}\text { Standardized } \\
\text { coefficients }\end{array}$} \\
\hline B & Std error & Beta & $\mathrm{t}$ & Sig \\
\hline Constant & -0.58 & 0.23 & & -2.47 & 0.014 \\
\hline Intrapersonal & -0.36 & 0.13 & -0.36 & -2.90 & 0.004 \\
\hline Interpersonal & 1.00 & 0.12 & 0.79 & 8.54 & 0.000 \\
\hline Stress Management & -0.30 & 0.14 & 0.13 & 2.20 & 0.029 \\
\hline Adaptability & 0.21 & 0.17 & -0.24 & 1.18 & 0.237 \\
\hline General mood & 0.58 & 0.13 & 0.49 & 4.59 & 0.000 \\
\hline
\end{tabular}

Note: $\mathrm{R}^{2}=.656$, Adj. $\mathrm{R}^{2}=.649, \mathrm{R}=.810, \mathrm{~F}=86.98, \mathrm{p}<.005$.

* Dependent variable: Transformational leadership

$*$ Regression equation can be formed as $\mathrm{TL}=-0.58-0.36$ Intrapersonal + Interpersonal -0.30 stress Management $++.58 \mathrm{General}$ mood .

The results also show the coefficients of the regression equation formed in the prediction of TL by the five dimensions of EI. The area of interest in this table has to do with the $t$ tests associated with the independent variables. Surprisingly, it can be seen that only Intrapersonal, Interpersonal, Stress Management and General mood have a significant t-statistic at 5\% significant level $(\mathrm{p}=.000)$. These6 results confirm the study of Polychroniou (2009) who concluded that the leaders who possess interpersonal intelligence may be associated with TL for several reasons.

On the other hand, only the dimension of Adaptability does not have a significant t-statistic ( $\mathrm{p}>$ 0.05). Adaptability may therefore be ignored in the regression equation linking up with TL. Though TL is significantly related by the five dimensions of EI, only Intrapersonal, Interpersonal, Stress Management and General mood are worth consideration in its prediction. This may due to Adaptability or the ability of leader to cope with environmental demands and pressures, have contributed their influences on EI, which in turn influences TL.

According to these results, a relationship between TL style and EI was found. Since, the regression analysis suggested that TL style of managers in tourism could be predicted from their EI scores. These results matched with past studies which have stressed the importance of EI for effective leadership (Goleman, 1998b). 
The findings of the current study are also consistent with other researchers (Rahim et al., 2002, 2006; Polychroniou, 2009; Mathew and Gupta, 2015) who emphasize the importance of EI on TL. As, transformational leaders who possess EI are likely to exhibit behaviors associated with increasing effectiveness and handling conflict with subordinates for positive outcomes on teamwork.

\subsection{Testing Equality of EI and TL Mean Regarding Business Type}

The mean TL score of managers in hotels was higher than that of managers in travel agents (3.13 and 2.93 respectively). Similarly, the mean EI score for managers in hotels was slightly higher than that for managers in travel agents (3.31 and 3.14 respectively). A summary of the descriptive statistics for hotels and travel companies is presented in Table 5.

Table 5: Mean Scores of EI and TL of Hotels and Travel Agent Managers

\begin{tabular}{lcccccc}
\hline Variables & \multicolumn{3}{c}{ Hotel managers } & \multicolumn{3}{c}{ Travel agents managers } \\
\hline & Mean & $\begin{array}{c}\text { St. } \\
\text { deviation }\end{array}$ & $\mathrm{N}$ & Mean & $\begin{array}{c}\text { St. } \\
\text { deviation }\end{array}$ & $\mathrm{N}$ \\
& 3.13 & .65 & 119 & 2.93 & .76 & 119 \\
$\begin{array}{l}\text { Transformational } \\
\text { leadership }\end{array}$ & 3.31 & .51 & 113 & 3.14 & .59 & 113 \\
$\begin{array}{l}\text { Emotional } \\
\text { Intelligence }\end{array}$ & & & & & & \\
\hline
\end{tabular}

Independent groups' T-test was used to compare the total mean of transformational and EI scores of managers in hotels and travel companies managers. A significant $(\mathrm{p}<0.05)$ difference was found in both the $\mathrm{TL}$ and the EI scores with $\mathrm{t}=2.16$ and 2.27 respectively.

These results may due to the financial ability of hotels comparing to travel companies. So hotels can present effective management training programs. These programs are usually designed to develop skills of leadership (Choi and Dickson, 2010).

On the other hand, there is not so much information regarding training management programs in travel companies. Even when great care is taken in designing programs or evaluating procedures, it is difficult to determine the exact effects of training on learning, behavior, and result (Pochanajun, 2011). This may return to that most of travel companies in Egypt are considered medium or small enterprises.

Moreover, the hierarchical regression analysis was also used to examine the interaction of business type (hotel and travel companies) with EI while predicting TL style. To test this, business type was added as a predictor in EI and transformational interaction. The difference in the $\mathrm{R}^{2}$ values was $-0.001,(\mathrm{t}=-0.689, \mathrm{P}$ $>0.05$ ). Surprisingly, contrary to the results above, the results of regression suggested that there is no difference in the relationship between EI and TL style of hotels and travel agents managers.

\section{Conclusion}

By reviewing a considerable number of studies, it is observed that TL has a definite positive correlation with EI. According to studies carried out in varied environments emotionally competent leaders at different levels of management are more successful in their organization and they are able to encourage and transform the people and work culture by their individual personality traits and inspirational motivating power. However, there remains limited empirical evidence that the two concepts are significantly related in both the tourism and hospitality industry.

In summary, the researchers attempted to look at the relationship between TL style and EI by examining the predictive relationship between EI and TL style in tourism and hospitality industry. Moreover, the present research try to identify which components of EI are more associated with supervisor's TL style. 


\section{Examining the Relationship between Emotional Intelligence and Transformational leadership: Evidence from Hotels and Travel Companies}

Lastly, the researchers investigated if there is any difference in the relationship between EI and TL style with respect to the business type.

The current study produced some valuable results having implications for both theory and practice. The correlation and regression results indicated that EI of leaders in hotels and tourism companies had a positive impact on TL. Also, the results revealed that the predictive power of EI was explained by only the dimensions "Intrapersonal, Interpersonal, Stress Management and General mood". Despite, the significant difference found between the mean score of the TL and the EI of the hotels and travel agents leaders, the researchers found no significant interaction between business type and EI while predicting TL style.

The application of the positive relationship between TL and EI could benefit hotels and travel agents in several ways. Knowledge of this relationship would help the top management identify and train potential leaders. If EI scores can predict TL, top management may find EI measures to be valuable tools in the selection process of hiring, promotion and development of hotel or travel company's leaders. It is recommended to design and organize training and development programs for employees, especially managers and supervisors, to equip them with a higher level of EI. This recommendation is held in the light of the argument that EI can be learned and acquired (Golman, 1995). Furthermore, it is possible to create El roadmaps for guided interaction between TL and EI to enhance TL. Assessment could identify those specific El dimension that need to be strengthened in order to effect the TL style., the findings presented in this paper illustrated the main effective dimensions of EI, if the organizations pay more attention to these dimensions in the workplace, it will lead to increase the TL style.

Although this study has generated interesting findings regarding the relationship between TL and El and has provided some suggestions for continued research for applying El in order to enhance the TL style, the findings need to be replicated on larger and diverse organizations in tourism and hospitality industry. Methodologically, we have limited our analysis to the MLQ and (EQ-i). Other instruments concerning transformational or measuring EI leadership might reveal other results. Moreover, the study may also add valuable results if other variables like cultural background, gender, age, experience, top management, and type of work setting are taken into account.

\section{References}

- Alsayed, A., Motaghi, M. and Osman, I. (2012). The Use of the Multifactor Leadership Questionnaire and Communication Satisfaction Questionnaire in Palestine: A Research Note. International Journal of Scientific and Research Publications, Vol. 2, No. 11, Pp. 1-9.

- Antonakis, J. (2003). Why emotional intelligence does not predict leadership effectiveness. The International Journal of Organizational Analysis, Vol. 11, No. 4, pp. 353-359.

- Antonakis, J., Bendahan, S., Jacquart, P. and Lalive, R. (2010). On making causal claims: A review and recommendations. The Leadership Quarterly, Vol. 21, No. 6, Pp. 1086-1120.

- Ashkanasy, N. M. and Daus, C. S. (2005). Rumors of the death of emotional intelligence in organizational behavior are vastly exaggerated. Journal of Organizational Behavior, Vol. 26, No. 4, 441452.

- Ashkanasy, N. and Tse, B. (2000). Transformational leadership as management of emotion: A conceptual review. IN: Ashkanasy, N., Hartel, C. and Zerbe, W. (Eds.), Emotions in the workplace: Research, theory and practice, Westport, Connecticut, Quorom Books.

- Avolio, B. and Gardner, W. (2005). Authentic leadership development: Getting to the root of positive forms of leadership. Leadership Quarterly, Vol. 16, No.3, Pp. 315-338.

- Bar-On, R. (1996). The Emotional Quotient Inventory: A measure of emotional intelligence. Toronto, ON: Multi Health Systems.

- Bar-On, R. (1997). Bar-On Emotional Quotient Inventory (EQ-i): Technical manual. Toronto, ON: Multi Health Systems. 
- Bass, B. M. (1990). From transactional to transformational leadership: Learning to share the vision. Organizational Dynamics, Vol. 18, No. 3, Pp. 19-31.

- Bass, B.M. and Avolio, B.J. (1996). Transformational Leadership Development: Manual for the Multifactor Leadership Questionnaire, Consulting Psychologists Press, Palo Alto, CA.

- Bass, B. M. and Avolio, B. J. (1997). Full Range Leadership Development: Manual for the Multifactor Leadership Questionnaire. Redwood, CA: Mind Garden.

- Bass, B.M. and Avolio, B.J. (2000). Multifactor Leadership Questionnaire. Kedwood City, CA: Mind Carden.

- Bass, B. M. and Riggio, R. E. (2006). Transformational leadership (2 ${ }^{\text {nd }}$ Ed.) Mahwah, NJ: Lawrence Erlbaum Associates.

- Bass, B. M. and R. E. Riggio (2008). Transformational Leadership. Mahwah, New Jersey: Lawrence Erlbaum Associates, Inc.

- Bono, J.E. and Judge, T.A. (2004), "Personality and transformational and transactional leadership: a meta-analysis", Journal of Applied Psychology, Vol. 89 No. 5, Pp. 901-11.

- Boyatzis, R., Goleman, D. and Rhee, K. (2000). Clustering competence in emotional intelligence: insights from the emotional competence inventory (ECI). IN: Bar-On, R. and Parker, J.D.A. (Eds), Handbook of Emotional Intelligence, Jossey-Bass, San Francisco, CA.

- Brackett, M. and Mayer, J. (2003). Convergent, discriminant, and incremental validity of competing measures of emotional intelligence. Personality and Social Psychology Bulletin, Vol. 29, No. 9, Pp. 1147-1158.

- Brown, F., Bryant, S. and Reilly, M. (2006). Does emotional intelligence - as measured by the EQI influence transformational leadership and/or desirable outcomes? Leadership and Organization Development Journal, Vol. 27, No. 5, Pp. 330 - 351.

- Brownell, J. (2010). Leadership in the Service of Hospitality. Cornell Hospitality Quarterly, Vol. 51, No. 3, Pp. 363-378.

- Burns J. (1978). Leadership, Harper and Row publishers, New York, NY. IN: Duckett H. Macfarlane, E. (2003) Emotional intelligence and transformational leadership in retailing. Leadership Organization Development Journal, Vol. 24, No. 6, pp. 309 - 317.

- Butler, C. J. and Chinowsky, P. S. (2006). Emotional intelligence and leadership behavior in construction executives. Journal of Management in Engineering, Vol. 22, No. 3, Pp. 119-125.

- Caruso, D. R., Mayer, J. D. and Salovey, P. (2002). Emotional intelligence and emotional leadership. IN: Riggio, R. E., Murphy, S. E., and Pirozzolo F. J. (Eds.). Multiple intelligences and leadership. Mahwah, NJ: Lawrence Erlbaum Associates.

- Cavazotte, F., Moreno, V. and Hickmann, M. (2012). Effects of leader intelligence, personality and emotional intelligence on transformational leadership and managerial performance. The Leadership Quarterly, Vol. 23, No.3, Pp. 443-455.

- Cherniss, C. (2001). Emotional intelligence and organizational effectiveness. IN: Cherniss C. and Goleman D. (Eds.). The emotionally intelligent workplace. San Francisco: Jossey-Bass.

- Choi, Y. and Dickson, D. (2010). A Case Study into the Benefits of Management Training Programs: Impacts on Hotel Employee Turnover and Satisfaction Level. Journal of Human Resources in Hospitality and Tourism, Vol. 9, No. 1, Pp., 103-116.

- Ciarrochi, J. V., Chan, A. C. and Caputi, P. (2001). A critical evaluation of the emotional intelligence construct", Personality and Individual Differences, Vol. 28, No. 3, Pp. 539-61. 
- Clarke, N. (2010). Emotional Intelligence and Its Relationship to Transformational Leadership and Key Project Manager Competences. Project Management Journal, Vol. 41, No. 2, Pp. 5-20.

- Clark, R. A., Hartline, M. D. and Jones, K. C. (2009). The effects of leadership style on hotel employees' commitment to service quality. Cornell Hotel and Restaurant Administration Quarterly, Vol., 50, No. 2, Pp. 209-231.

- Côté, S., Lopes, P., Salovey, P. and Miners, C. (2010). Emotional intelligence and leadership emergence in small groups, The Leadership Quarterly, Vol. 21, No. 3, Pp. 496-508.

- Danquah, E. and Wireko, T. (2014). The Impact of Each Element of Emotional Intelligence on Customer Service Delivery: A Customer Satisfaction Perspective. International Journal of Sales and Marketing Management Research and Development, Vol. 4, No. 2, Pp. 9-20.

- Day, A. L. and Carroll, S. A. (2004). Using ability-based measure of emotional intelligence to predict individual performance, group performance and group citizenship behavior. Personality and Individual Differences, Vol. 36, No. 6, Pp. 1443-1458.

- Duckett, H., and Macfarlane, E., (2003). Emotional intelligence and transformational leadership in retailing, Leadership Organization Development Journal, Vol. 24, No. 6, Pp. 309-317.

- Egyptian Hotel Association (2013). The Egyptian hotel guide, EHA Press, Cairo.

- Egyptian Travel Agents Association (2013). The Egyptian Travel Agent guide, EHA Press, Cairo.

- Follesdal, H. and Hagtvet, K. (2013). Does emotional intelligence as ability predict transformational leadership? A multilevel approach. The Leadership Quarterly, Vol. 24, No. 5, Pp. 747-762.

- Freedman, J. (2007). At the heart of Leadership: How to get results with Emotional Intelligence. Six Seconds, San Mateo, CA.

- Gardner, H. (1999). Intelligence Reframed, Basic Books, New York, NY.

- Gardner, L., and Stough, C. (2002). Examining the relationship between leadership and emotional intelligence in senior level managers. Leadership and Organization Development Journal, Vol. 23, No. 2, Pp. 68-78.

- Goleman, D. (1995). Emotional Intelligence. Bantam Books, New York, NY.

- Goleman, D. (1996). Emotional intelligence: Why it matters more than IQ. Learning, Vol. 24, No. 6, Pp. 49-50.

- Goleman, D. (1997). Beyond IQ: developing the leadership competencies of emotional intelligence. Paper presented at the 2nd International Competency Conference, London.

- Goleman, D. (1998a). Working with Emotional Intelligence, Bantam Books, New York, NY.

- Goleman, D. (1998b). What makes a leader? Harvard Business Review, Vol. 76, No. 6, Pp. 93-102.

- Goleman, D. (2001). An EI-based theory of performance. IN: Cherniss, C. and Goleman, D. (Eds), The Emotionally Intelligent Workplace: How to Select for, Measure, and Improve Emotional Intelligence in Individuals, Groups, and Organizations, Jossey-Bass, San Francisco, CA.

- Goleman, D., Mckee, A. and Boyatzis, R. (2002). Primal Leadership: Realizing the power of Emotional Intelligence. Cambridge, Harvard Business School Press.

- Harms, P. and Credé, M. (2010). Emotional Intelligence and Transformational and Transactional Leadership: A Meta-Analysis. Journal of Leadership and Organizational Studies, Vol. 17, No. 1, Pp. 517

- Hellriegel, D. and Slocum, J. (2004). Organizational Behavior. 10th ed., International Thomson Publishing, Andover. 
- Hellriegel, D., Jackson, S. and Slocum, J. (2005). Management. 10th ed., International Thomson Publishing, Andover.

- Hunt, J. and Fitzgerald, M. (2013). The Relationship between Emotional Intelligence and Transformational Leadership: An Investigation and Review of Competing Claims in the Literature. American International Journal of Social Science, Vol. 2, No. 8, Pp. 30-38.

- Judge, T.A., Ilies, R. and Colbert, A.E. (2004). Intelligence and leadership: a quantitative review and test of theoretical propositions", Journal of Applied Psychology, Vol. 89, No. 3, pp. 542-52.

- Kim, T., Yoo J., Lee, G. and Kim J. (2012). Emotional intelligence and emotional labor acting strategies among frontline hotel employees. International Journal of Contemporary Hospitality Management, Vol. 24, No.7, Pp. 1029 - 1046.

- Koroglu, O. and Koroglu, A. (2012). The importance of using emotional intelligence skills for tour guides and their performance. Management and education, Vol. 3, No. 3, Pp. 28-35.

- Lam, C. and O'Higgins, R., (2012). Enhancing employee outcomes", Leadership and Organization Development Journal, Vol. 33, No. 2, Pp. 149 - 174

- Lindebaum, D. and Cartwright, S. (2010). A critical examination of the relationship between emotional intelligence and transformational leadership, Journal of Management Studies, Vol. 47, No. 7, Pp. 13171342.

- Lisa, M. G. (2008). The Sage Encyclopedia of Qualitative Research Methods. SAGE Publications, Thousand Oaks, CA.

- Lopez-Zafra, E., Garcia-Retamero, R. and Martos, M. (2012). The relationship between transformational leadership and emotional intelligence from a gendered approach, The Psychological Record, 62, No. 1, Pp. 97-114.

- Lutzo, E. (2005). Resonant Leadership. Weatherhead Coaches Corner. Vol. 2, No. 11. http://www.forwardthought.net/articles/20051117ResonantLeadership.pdf

- Mandell, B. and Pherwani, S. (2003). Relationship between Emotional Intelligence and Transformational Leadership Style: A Gender Comparison. Journal of Business and Psychology, Vol. 17, No. 3, Pp. 387404.

- Mathew, M. and Gupta, K. (2015). Transformational Leadership: Emotional Intelligence. Quarterly Journal of Indian Management, Vol. 12, No. 2, Pp. 75-89.

- Matthews, G., Zeidner, M., and Roberts, R. D. (2002). Emotional Intelligence: Science and Myth. Cambridge, MA: MIT Press.

- Mayer, J., and Salovey, P. (1997). What is emotional intelligence? IN: P. Salovey, and D. Sluyter (Eds.), Emotional development and emotional intelligence: implications for educators. New York.

- Mayer, J. D., Salovey, P. and Caruso, D. R. (1997). The Multifactor Emotional Intelligence Scale (MEIS). Simsbury, CT: www.EmotionalIQ.com.

- Mayer, J., Salovey, P. and Caruso, D. (2002). Mayer-Salovey- Caruso Emotional Intelligence Test (MSCEIT) user manual. Toronto, Canada: Multi-Health Systems.

- Mayer, J., Salovey, P. and Caruso, D. (2004). Emotional intelligence: Theory, findings, and implications. Psychological Inquiry, Vol. 15, No. 3, 197-215.

- Megerian, L.E. and Sosik, J. J. (1996). An affair of the heart: Emotional intelligence and transformational leadership. Journal of Leadership Studies, Vol. 3, No. 3, Pp. 31-48.

- Nunnally, J. C. and Bernestein, I. H. (1994). Psychometric theory. (3 ${ }^{\text {rd }}$ Ed.). New York: McGraw-Hill. 
- Ölçer, F., Florescu, M. and Năstase, M. (2014). The Effects of Transformational Leadership and Emotional Intelligence of Managers on Organizational Citizenship Behaviors of Employees. Review of International Comparative Management Vol. 15, No. 4, Pp. 385-401.

- Palmer, B. and Stough, C. (2001). Workplace SUEIT: Swinburne University Emotional Intelligence Test—Descriptive report. Melbourne: Swinburne University, Organizational Psychology Research Unit, Australia.

- Palmer, B., Manochab, R., Gignaca, G. and Stougha, C. (2003). Examining the factor structure of the Bar-On Emotional Quotient Inventory with an Australian general population sample. Personality and Individual Differences, Vol. 35, No. 5, Pp. 1191-1210.

- Pochanajun, J. (2011). Development Training Program for Unskilled and Skilled Employee: A Case Study of Travel Agency in Bankok Thailand. Master of Business Administration Program in Hotel and Tourism Management, Program of Hotel and Tourism Management International program, Graduate School, Silpakorn University.

- Podsakoff, P.M., MacKenzie, S. B., Lee, J.Y. and Podsakoff, N. P. (2003). Common method biases in behavioral research: A critical review of the literature and recommended remedies. Journal of Applied Psychology, Vol.88, No. 5, Pp. 879-903.

- Polychroniou, P. (2009). Relationship between emotional intelligence and transformational leadership of supervisors: The impact on team effectiveness. Team Performance Management, Vol. 15, No. 8, Pp. 343 $-356$.

- Prati, L.M., Douglas, C., Ferris, G.R., Ammeter, A.P. and Buckley, M.R. (2003). Emotional intelligence, leadership effectiveness, and team outcomes. International Journal of Organizational Analysis, Vol. 11, No. 1, Pp. 21-40.

- Rahim, M.A., Psenicka, C., Zhao, J.H., Yu, C.S., Polychroniou, P., Chan, K.A., Yee, K.W., Alves, M.G., Lee, C.W., Rahman, M.S., Ferdausy, S. and Wyk, R.V. (2002). A model of emotional intelligence and conflict management strategies: a study in seven countries. International Journal of Organizational Analysis, Vol. 10, No. 4, Pp. 302-326.

- Rahim, M.A., Psenicka, C., Polychroniou, P., Oh, S.Y., Ferdausy, S. and Dias, J.F. (2006). Emotional intelligence and transformational leadership: a group level analysis in five countries. Current Topics in Management, Vol. 11, No. 1, Pp. 223-236.

- Rosete, D. and Ciarrochi, J. (2005). Emotional intelligence and its relationship to workplace performance outcomes of leadership effectiveness. Leadership and Organization Development Journal, Vol. 26, No. 5, Pp. 388-399.

- Rybochkina, D. (2010). Emotional intelligence and its application in the hospitality industry. Contemporary issues in hospitality student journal, Vol. 1, Pp. 1-7.

- Salovey, P. and Grewal, D. (2005). The science of emotional intelligence. Current Directions in Psychological Science, Vol. 14, No. 6, Pp. 281-285.

- Salovey, P. and Mayer, J.D. (1994). Some final thoughts about personality and intelligence. IN: Sternberg, R.J. and Ruzgis, P. (Eds), Personality and Intelligence, Cambridge University, Press, Cambridge.

- Schlechter, A. and Strauss, J. (2008). Leader emotional intelligence, transformational leadership, trust and team commitment: testing a model within a team context, SA Journal of Industrial Psychology, Vol. 34 No. 1 Pp. $42-53$.

- Sivanathan, N. and Fekken, G. (2002). Emotional intelligence, moral reasoning and transformational leadership. Leadership and Organization Development Journal, Vol. 23, No. 4, Pp. 198-204. 
- Sosik, J.J. and Godshalk, V. M. (2000). Leadership styles, mentoring functions received, and job-related stress: a conceptual model and preliminary study. Journal of Organizational Behavior, Vol. 21, No. 4, Pp. 365-390.

- Sosik, J.J. and Megerian, L.E. (1999). Understanding leader emotional intelligence and performance the role of self other agreement on transformational leadership perceptions. Group and Organization Management, Vol., 24, No. 3, Pp. 367-390.

- Van Rooy, D.L. and Viswesvaran, C. (2004). Emotional Intelligence: A meta-analytic investigation of predictive validity and nomological net. Journal of Vocational Behavior, Vol. 65, No. 1, Pp. 71-95.

- Wilmot, A. (2002). Designing sampling strategies for qualitative social research: with particular reference to the Office for National Statistics' Qualitative Respondent Register. Available at:http://wwwn.cdc.gov/qbank/QUest/2005/Paper23.pdf ,(accessed on 12th April 2015)

- Zikmund W.G., Babin, B., Car, J. and Griffin, M. (2013). Business research methods. Ninth edition, International edition, Published Australia: South-Western.

\section{Endnote:}

In this paper Travel Companies refer to both tour operators and travel agents 


\section{Appendix \\ The Study Questionnaires}

\section{A) Managers Questionnaire: Emotional Quotient Inventory (EQ_i)}

Please judge how frequently each statement fits you as $\mathbf{1}=$ Very Seldom or Not true of me, to $\mathbf{5}=$ Very often true of me or True of me.

\begin{tabular}{|c|c|c|c|c|c|}
\hline 1. Intrapersonal & & & & & \\
\hline 1.I.Self-Regard & & & & & \\
\hline -I feel sure of myself in most situations. & 1 & 2 & 3 & 4 & 5 \\
\hline - I have a self-confidence. & 1 & 2 & 3 & 4 & 5 \\
\hline - I have a good self-respect. & 1 & 2 & 3 & 4 & 5 \\
\hline - I feel good about myself. & 1 & 2 & 3 & 4 & 5 \\
\hline I.2 Emotional Self-Awareness & & & & & \\
\hline -It's fairly easy for me to express feelings. & 1 & 2 & 3 & 4 & 5 \\
\hline -I'm in touch with my emotions. & 1 & 2 & 3 & 4 & 5 \\
\hline - It's easy for me to share my deep feelings with others. & 1 & 2 & 3 & 4 & 5 \\
\hline - It's easy for me to understand the way I feel. & 1 & 2 & 3 & 4 & 5 \\
\hline I.3 Assertiveness & & & & & \\
\hline -I'm able to express my ideas to others. & 1 & 2 & 3 & 4 & 5 \\
\hline - When I'm angry with others, I can tell them about it. & 1 & 2 & 3 & 4 & 5 \\
\hline -When I disagree with someone, I'm able to say so. & 1 & 2 & 3 & 4 & 5 \\
\hline - It's easy for me to say "no" when I want to. & & & & & \\
\hline I.4 Independence & & & & & \\
\hline - I prefer a job in which I'm told pretty much what to do. & 1 & 2 & 3 & 4 & 5 \\
\hline $\begin{array}{l}\text { - When working with others, I do not tend to rely more on their ideas } \\
\text { than my own. }\end{array}$ & 1 & 2 & 3 & 4 & 5 \\
\hline - I do not prefer others to make decisions for me. & 1 & 2 & 3 & 4 & 5 \\
\hline - It's easy for me to make decisions on my own. & 1 & 2 & 3 & 4 & 5 \\
\hline I.5 Self-Actualization & & & & & \\
\hline -I try to make my life as meaningful as possible. & 1 & 2 & 3 & 4 & 5 \\
\hline
\end{tabular}




\begin{tabular}{|c|c|c|c|c|c|}
\hline - I really know what I'm good at. & 1 & 2 & 3 & 4 & 5 \\
\hline - In the past few years I've accomplished great. & 1 & 2 & 3 & 4 & 5 \\
\hline - I get enjoyment from what I do. & 1 & 2 & 3 & 4 & 5 \\
\hline \multicolumn{6}{|l|}{$\underline{\text { 2. Interpersonal }}$} \\
\hline \multicolumn{6}{|l|}{ 2.I Empathy } \\
\hline - I'm good at understanding the way other people feel. & 1 & 2 & 3 & 4 & 5 \\
\hline - My friends can tell me intimate things about themselves. & 1 & 2 & 3 & 4 & 5 \\
\hline $\begin{array}{l}\text { - I would stop and help any person who needs my help, even if I had to } \\
\text { be somewhere else at the same time. }\end{array}$ & 1 & 2 & 3 & 4 & 5 \\
\hline \multicolumn{6}{|l|}{ 2.2 Social Responsibility } \\
\hline - I like helping people. & 1 & 2 & 3 & 4 & 5 \\
\hline $\begin{array}{l}\text { - It doesn't bother me to give advantages to people especially if they } \\
\text { deserve it. }\end{array}$ & 1 & 2 & 3 & 4 & 5 \\
\hline - Others find it easy to depend on me. & 1 & 2 & 3 & 4 & 5 \\
\hline - I care what happens to other people. & 1 & 2 & 3 & 4 & 5 \\
\hline \multicolumn{6}{|l|}{ 2.3 Interpersonal Relationship } \\
\hline - I'm able to show affection. & 1 & 2 & 3 & 4 & 5 \\
\hline - It's easy for me to share my deep feelings with others. & 1 & 2 & 3 & 4 & 5 \\
\hline - I'm a fairly cheerful person. & 1 & 2 & 3 & 4 & 5 \\
\hline - It's easy for me to make friends. & 1 & 2 & 3 & 4 & 5 \\
\hline \multicolumn{6}{|l|}{ 3. Stress Management } \\
\hline \multicolumn{6}{|l|}{ 3.1 Stress Tolerance } \\
\hline - I know how to deal with upsetting problems. & 1 & 2 & 3 & 4 & 5 \\
\hline - I believe that I can stay on top of tough situations. & 1 & 2 & 3 & 4 & 5 \\
\hline - I can handle stress without getting too nervous. & 1 & 2 & 3 & 4 & 5 \\
\hline - I can hold up well under stress. & 1 & 2 & 3 & 4 & 5 \\
\hline \multicolumn{6}{|l|}{ 3.2 Impulse Control } \\
\hline - It is not a problem controlling my anger. & 1 & 2 & 3 & 4 & 5 \\
\hline
\end{tabular}




\section{Examining the Relationship between Emotional Intelligence and Transformational leadership: Evidence from Hotels and Travel Companies}

\begin{tabular}{|c|c|c|c|c|c|}
\hline - When I start talking, it is not hard to stop. & 1 & 2 & 3 & 4 & 5 \\
\hline - My impulsiveness do not creates problems. & 1 & 2 & 3 & 4 & 5 \\
\hline - People do not tell me to lower my voice in discussions. & 1 & 2 & 3 & 4 & 5 \\
\hline \multicolumn{6}{|l|}{ 4. Adaptability } \\
\hline \multicolumn{6}{|l|}{ 4.1 Reality-Testing } \\
\hline $\begin{array}{l}\text { - I try to see things as they really are, without fantasizing or } \\
\text { daydreaming about them. }\end{array}$ & 1 & 2 & 3 & 4 & 5 \\
\hline - I have had strange experiences that can't be explained. & 1 & 2 & 3 & 4 & 5 \\
\hline - People usually understand the way I think. & 1 & 2 & 3 & 4 & 5 \\
\hline - I tend to keep contact with what happens around. & 1 & 2 & 3 & 4 & 5 \\
\hline \multicolumn{6}{|l|}{ 4.2 Flexibility } \\
\hline - It's easy for me to begin new things. & 1 & 2 & 3 & 4 & 5 \\
\hline - It's easy for me to make adjustments in general. & 1 & 2 & 3 & 4 & 5 \\
\hline - It's acceptable for me to change my opinion about things. & 1 & 2 & 3 & 4 & 5 \\
\hline - It's easy for me to adjust to new conditions. & 1 & 2 & 3 & 4 & 5 \\
\hline \multicolumn{6}{|l|}{ 4.3 Problem-Solving } \\
\hline - My approach to overcoming difficulties is to move step by step. & 1 & 2 & 3 & 4 & 5 \\
\hline $\begin{array}{l}\text { - When faced with a difficult situation, I like to collect all the } \\
\text { information about it that I can. }\end{array}$ & 1 & 2 & 3 & 4 & 5 \\
\hline - I like to get an overview of a problem before trying to solve it. & 1 & 2 & 3 & 4 & 5 \\
\hline - When facing a problem, the first thing I do is stop and think. & 1 & 2 & 3 & 4 & 5 \\
\hline \multicolumn{6}{|l|}{ 5. General Mood } \\
\hline \multicolumn{6}{|l|}{ 5.1 Optimism } \\
\hline - I'm optimistic about most things. & 1 & 2 & 3 & 4 & 5 \\
\hline - I generally hope for the best. & 1 & 2 & 3 & 4 & 5 \\
\hline - I'm generally motivated to continue even when things get difficult. & 1 & 2 & 3 & 4 & 5 \\
\hline $\begin{array}{l}\text { - I generally expect things will turn out all right despite setbacks from } \\
\text { time to time. }\end{array}$ & 1 & 2 & 3 & 4 & 5 \\
\hline
\end{tabular}




\begin{tabular}{|l|l|l|l|l|l|}
\hline 5.2 Happiness & 1 & 2 & 3 & 4 & 5 \\
\hline - It's easy for me to enjoy life. & 1 & 2 & 3 & 4 & 5 \\
\hline - It's easy for me to smile. & 1 & 2 & 3 & 4 & 5 \\
\hline - I am satisfied with my life. & 1 & 2 & 3 & 4 & 5 \\
\hline - I'm fun to be with. & & & \\
\hline
\end{tabular}

Demographic data: Choose the appropriate answer for the following items:

\section{Sex}
Male
$\square$ Female

2. Age

Less than 35 years

From 35 to 45 years

$\square$ More than 45 years

3. Experience

Less than 5 years

From 5-10 years

More than 10 years

\section{Education}
Secondary/High School
College/University
Postgraduate Degree

\section{Team size}

below 10team members

From 10-20 team members

More than 20 team members

\section{Management Level}

Vice president

Middle managers
High level managers

$\square$ Department head and supervisors

Thank you for your cooperation 


\section{B) Employee Questionnaire: Multifactor Leadership Questionnaire (MLQ)}

Please measure the degree of your manager leadership attitudes from $1=$ not at all, $2=$ once in a while, $3=$ sometimes, $4=$ fairly often and $5=$ frequently

\begin{tabular}{|c|c|c|c|c|c|}
\hline \multicolumn{6}{|l|}{ 1- Idealized influence } \\
\hline 1.1. My manager makes others feel good to be around him. & 1 & 2 & 3 & 4 & 5 \\
\hline 1.2. We have complete faith in him. & 1 & 2 & 3 & 4 & 5 \\
\hline 1.3. We are proud to be associated with him. & 1 & 2 & 3 & 4 & 5 \\
\hline 1.4.My manager goes beyond self-interest for the good of the group & 1 & 2 & 3 & 4 & 5 \\
\hline \multicolumn{6}{|l|}{ 2-Inspirational motivation } \\
\hline 2.1. My manager talks optimistically about the future. & 1 & 2 & 3 & 4 & 5 \\
\hline $\begin{array}{l}\text { 2.2. My manager expresses with a few simple words what we could and should } \\
\text { do. }\end{array}$ & 1 & 2 & 3 & 4 & 5 \\
\hline 2.3. My manager provides appealing image about what we can do. & 1 & 2 & 3 & 4 & 5 \\
\hline 2.4. My manager talks enthusiastically about what needs to be accomplished. & 1 & 2 & 3 & 4 & 5 \\
\hline 2.5. My manager helps others to find meaning in their work. & 1 & 2 & 3 & 4 & 5 \\
\hline \multicolumn{6}{|l|}{ 3-Intellectual stimulation } \\
\hline 3.1. My manager enables others to think about old problems in new ways. & 1 & 2 & 3 & 4 & 5 \\
\hline 3.2. My manager provides others with new ways of looking at puzzling things. & 1 & 2 & 3 & 4 & 5 \\
\hline $\begin{array}{l}\text { 3.3. My manager gets others to rethink ideas that they had never questioned } \\
\text { before. }\end{array}$ & 1 & 2 & 3 & 4 & 5 \\
\hline \multicolumn{6}{|l|}{ 4-Individual consideration } \\
\hline 4.1My manager spends time teaching and coaching. & 1 & 2 & 3 & 4 & 5 \\
\hline 4.2. My manager helps others develop themselves. & 1 & 2 & 3 & 4 & 5 \\
\hline 4.3. My manager lets others know how he thinks they are doing. & 1 & 2 & 3 & 4 & 5 \\
\hline 4.4. My manager gives personal attention to others who seem rejected. & 1 & 2 & 3 & 4 & 5 \\
\hline
\end{tabular}

Thank you for your cooperation 


\section{التحقى من العلاقة بين الذكاء العاطفى والقيادة التحويلية :دراسة عن الفنادق وشركات السياحة}

$$
\text { الملخص العربى }
$$

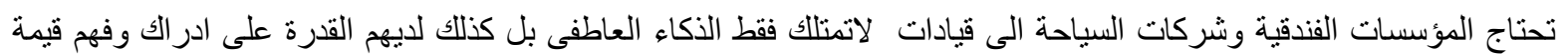

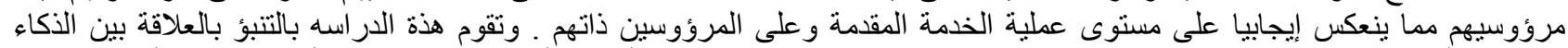

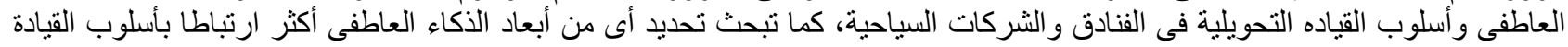

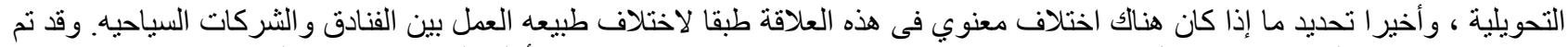

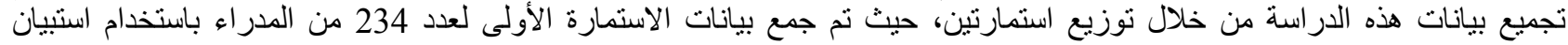
Emotional Quotient Inventory (EQ-i) Multifactor Leadership (MLQ)

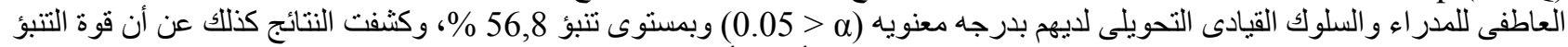

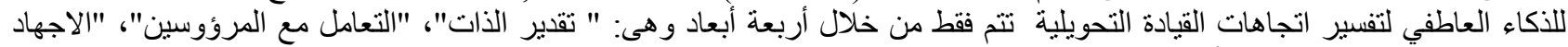

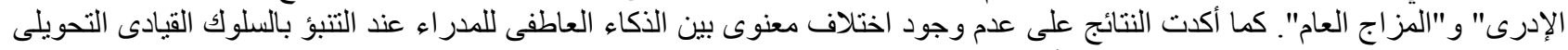

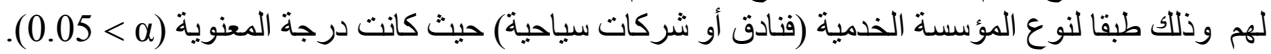

